\title{
The long-term impact of foreign multinational enterprises in Spain: new insights into an old topic
}

\begin{abstract}
The role of foreign capital and technology in the economic and social progress of late-developing countries remains a controversial issue in both academic and policy circles. In this essay, we examine the case of Spain in the light of the academic literature from the 1960s to the present. First, we identify and contextualize the intellectual concerns and controversies of two important generations of economists and historians and their approaches to the specific issue of multinational enterprises (MNEs). We then discuss what we consider to be the seven major contributions of recent Spanish scholarship in terms of: (1) new quantitative evidence on FDI inward flows and firm demography analyses of foreign MNEs; (2) new approaches to the transfer of technology by MNEs; (3) collective and individual case studies of foreign MNEs, with a focus on their impact on local capabilities; (4) identification of patterns of investment by MNE home countries; (5) identification and study of the local actors of inward FDI; (6) new perspectives gained from the history of international relations; and (7) new evidence on processes leading from inward FDI to outward FDI. We argue that the time is ripe for comprehensive re-assessments of the long-term impact of foreign MNEs and the role of Spain in the global economy.
\end{abstract}

Keywords: Multinational Enterprise; Foreign Direct Investment; Spain; Spillovers

Corresponding author. E-mail: nuriapuig@ccee.ucm.es

Received 29 April 2016 - Accepted 30 May 2016

This is an Open Access article distributed under the terms of the Creative Commons Attribution-Non-Commercial-No Derivatives License (http://creativecommons.org/licenses/by-nc-nd/4.0/), which permits non-comercial re-use and distribution, provided the original work is properly cited, and is not altered or transformed in any way. 
This essay explores an old controversy that has confronted generations of political economists: Do MNEs contribute to the social and economic progress of late developing countries, enabling the development of local actors and assets, as the international business literature predicts (Dunning and Lundan 2008, 314-318)? Or, rather, do MNEs tend to perpetuate backwardness, by constraining institutional arrangements and increasing technological dependence through production enclaves, alliances with local oligarchies and corrupt practices, as the theories of dependency point out (Vernon 1971; Moran 1974; Cardoso and Faleto 1979; Evans 1979)?

After more than fifty years of academic research on the multinational enterprise, there is still no convincing answer to these questions. Research in the fields of international business, technology transfer and the history of multinationals has certainly produced a wealth of quantitative and qualitative evidence across the globe. According to scholarship, the transfer of knowledge and capabilities tends to work well within advanced countries, promoting convergence, but this is not the case in less developed economies, where this process is frequently hindered by inadequate institutions and low levels of human capital (Jones 2014). There is, anyway, little or no aggregate evidence of spillovers from MNEs to local firms, and no strong empirical evidence of the positive impact of foreign MNEs beyond positive linkages between MNEs and local suppliers (Jones 2014, 191-194). The impact of multinational firms on host economies is, furthermore, multifaceted (Wilkins 1998, 2009, 2010; Jones 2005, 2014). MNEs can be important modes of technology transfer and are quite often sizable employers of labor, as international business and economics have noted (Lipsey 2002; Dunning and Lundan 2008), but, they also have major social and cultural impacts which cannot be captured by the usual tools of the aforementioned disciplines. In this sense, the historical perspective and method employed have great potential to assess both the 
desirable and adverse outcomes -externalities- of foreign MNEs. Despite this, economic and business history literature, although strong "on the drivers of the growth of global business and its organizational structures and diversity", has until now failed to answer convincingly "whether the net impact of global business was positive or negative" (Jones 2015, 404). Mira Wilkins, the dean of MNE history, gives some directions for future research, linked to the challenges faced by historians at the macro and micro levels: to determine why the same MNE affects host states in both similar and dissimilar manners, eventually shaping national capitalism; to discover which interactions and which government policies in what context stimulate national economic growth; and to find out what makes one society and not another able to borrow from, and effectively shape, the contributions of MNEs toward national goals (Wilkins 2010, 645).

This essay goes into this controversy about the long-term impact of foreign MNEs on host economies focusing on the case of Spain, as a late industrializing country, with a twofold aim: to examine major scholarly contributions to identify new directions for future research, and to encourage new comparative and multidisciplinary research. The article is structured as follows. First, we argue why Spain is an attractive case study to later contextualize in section two the intellectual concerns, controversies and approaches of the earliest scholarship on inward FDI in the country. We then discuss what we consider to be the seven major contributions of recent Spanish research on this issue, focusing on economic and business historians' works. Last section is, finally, devoted to conclusion and directions for future research.

\section{Spain as a case study}

Spain became an attractive destination for foreign direct investment with the spread of industrialization in the $19^{\text {th }}$ century (G. Tortella 1973; T. Tortella 2000). Although the existing 
evidence on historical inward capital flows and the number and operations of foreign firms is rather fragmented, we know that four countries have traditionally concentrated foreign concerns in the country: France, Britain, Germany and the United States (Puig, Álvaro and Castro 2008a). Whereas French and British capital was prominent in the $19^{\text {th }}$ century, focusing on mining, railway and banking, German and American firms would take the lead during the Second Industrial Revolution and from the 1880s onwards. Their influence reached peaks during the early 1940s and the 1960s, respectively. After Spain became a full member of the European Union in 1986, European investors gained in importance among Spain's total inward capital flows.

Spain's economic and institutional performance and, in particular, economic policy, shaped foreign MNEs' operations in the country at least in terms of entry strategies and staffing and recruiting patterns. Protectionism (between 1892 and the 1960s), economic nationalism (from the 1930 s to the 1960s) and international isolation (from the 1930s to the 1950s) indeed promoted joint ventures and strategic alliances with local partners and the recruitment of local managers and staff. (Puig and Álvaro-Moya 2015b). MNEs, moreover, contributed to the rise of powerful business groups, which used the capital, knowhow and contacts provided by their foreign partners to grow and diversify (Muñoz, Roldán and Serrano 1978; Guillén 2000; Kock and Guillén 2001; Valdaliso 2006; Valdaliso and Torres 2012; Puig and Torres 2008, 2015; Álvaro-Moya 2011). Spain, therefore, constitutes an excellent testing ground for the longterm impact of protectionist policies on foreign MNEs and their interplay with local actors, a traditional issue, recently revisited, among scholars who have examined inward FDI in the country. 


\section{Early research on inward FDI in Spain}

Early research on inward FDI focused on Spain's historical backwardness and the Spanish "nationalistic path to capitalism". Under the influence of both postwar modernization theory (Rostow 1960; Gerschenkron 1962) and Marxist development economics (Prebisch 1950), economists and historians would embark on a fruitful interdisciplinary dialogue to assess whether MNEs had helped or prevented the rise of modern capitalism in $19^{\text {th }}$-century Spain. The absence or irrelevance of spillovers from massive foreign investment in mining and railways led many economic historians to adopt a rather negative view. According to this, MNEs were not a push factor in the overall process of industrialization, but instead reinforced Spain’s backwardness (Sardà 1948; Campillo 1963; Tamames 1967; Sánchez-Albornoz 1968; Cameron 1971; Nadal 1975; Broder 1979). Scholars interested in more contemporary issues built on such statements to construct a comprehensive theory of Spanish capitalism. Mounting economic nationalism under successive political regimes, they affirmed, paved the way for General Franco's self-sufficiency project (1939-1959) (Roldán and García Delgado 1973; Clavera et al. 1973). Other scholars, however, argued that foreign investment was crucial to developing not only strategic industries such as railways but also universal banking, which could not have developed without foreign investors due to the lack or insufficiency of private savings and the chronic problem of public deficit (Tortella 1973). Indeed, both foreign and national enterprises behaved similarly, responding to economic incentives and seizing business opportunities. Governmental efforts to attract foreign capital explains not only how opportunities were exploited by MNEs, but also the introduction of the more liberal policies which encouraged inward capital flows and Spain's integration into world markets (Costa Campí 1983). 
MNEs became particularly visible during the 1960s and early 1970s, the period of rapid growth that allowed Spain to complete its industrialization. This gave rise to scholarly analyses on two interrelated issues. The first was the study of Spain's structural dependence on foreign, primarily American, capital and knowledge, supported by aggregate data on imports of capital goods, patents registered by foreign firms and contracts of technical assistance (Velarde 1975; Gallego 1975; Braña, Buesa and Molero 1976; García Delgado and Segura 1977; Fanjul and Segura 1977; Molero 1979). The second concerned the relationship between foreign investors and the local business and financial elite (Muñoz 1969; Tamames 1977). These analyses were based to a large extent on the first comprehensive reconstruction of the inward flows and vehicles of foreign capital in Spain during the 1960s and 1970s, a seminal work authored by three economists and entitled La internacionalización del capital en España, 1959-1977 (Muñoz, Roldán and Serrano 1978). Its publication coincided with the elaboration by the Spanish Ministry of Trade of the first census of Spanish firms with participation by foreign corporations (Ministerio de Comercio 1977). This study showed that foreign, and in particular, American firms played a prominent role in the Spanish manufacturing sector, especially in the motor, chemical and electrical industries. Interestingly, most of the literature held a critical view of foreign MNEs and their local partners, blaming them for Spain's relative backwardness. Some authors, however, pointed at local institutions and the lack of an entrepreneurial drive as the main causes of Spain's economic and social deficiencies (Velarde 1969; Tortella 1973).

The traditional view of Spain's backwardness, dependency and entrepreneurial failure has had a lasting influence on Spanish social scientists. Nevertheless, the dynamism of the Spanish economy in the late $20^{\text {th }}$ and early $21^{\text {st }}$ centuries, in particular the firms that went international in the late $20^{\text {th }}$ century or even earlier, began to challenge the traditional, pessimistic 
approach. What is more, the wave of corporate mergers and acquisitions prompted by Spain's entry into the European Union in the late 1980s would shed new light on the potential and capabilities of Spanish firms, encouraging scholars to reconsider the role of foreign investment in the organizational development of Spanish companies. The topic has turned out to be a remarkably fertile one, particularly for management scholars investigating the rise of what have been recently called the "new multinationals" (Guillén and García Canal 2010). These new multinationals, that include companies from emerging markets, have been able not only to imitate the established ones, but also to develop their own competitive advantages based on the exploitation of firm-specific competences (Durán 1996, 1998, 2005, 2006) and the exploration of new patterns of innovation and ways of accessing markets (Guillén 2005; Guillén and García Canal 2010).

\section{Recent historical research on inward FDI in Spain}

In contrast to the fruitful dialogue between economists and historians that characterized the previous period, recent academic research on inward FDI has been carried out with little interaction across disciplines. It should be noted that Spanish economic and business historians, most of whom are affiliated with departments of Economics and Management, have integrated theoretical frameworks such as Dunning's eclectic paradigm and Uppsala's gradual internationalization model into their studies. Needless to say, they have been also influenced by the work of international business historians like Mira Wilkins, Alfred Chandler and Geoffrey Jones.

Their university colleges, however, have been considerably less receptive to the extensive historical research conducted in the past decades within or outside Spain. Therefore, in this section we want to discuss what we think of as the main contributions of recent historical 
research regarding inward FDI and MNEs in contemporary Spain. We have identified seven lines of research: new quantitative evidence on FDI inward flows and firm demography analyses of foreign MNEs; new approaches to the transfer of technology by MNEs; collective and individual case studies of foreign MNEs, with a focus on their impact on local capabilities; identification of patterns of investment by MNE home countries; identification and study of the local actors of inward FDI; new perspectives gained from the history of international relations; and, finally, new evidence on processes leading from inward FDI to outward FDI.

\section{FDI inward flows and firm demography}

Inward FDI flows did not begin to be systematically recorded by the Bank of Spain until 1975. There is only fragmented quantitative evidence, recorded by the Spanish Administration, on Spanish firms controlled by foreign MNEs between 1959 and 1975, and this has been used by successive generations of scholars to assess the relevance and long-term impact of foreign capital in the Spanish economy, particularly in the industrial sector. As a result, early reconstructions of FDI inward flows did not provide a long-term overview, nor did the first efforts to build corporate censuses. As the latter were based on the directories of joint-stock companies, they focused on mining and railways (Campillo 1963; Sáinz 1965).

A new wave of research has overcome these limitations by looking for alternative sources, such as diplomatic, counter-intelligence and corporate records, which include contemporary censuses of foreign firms and broad estimations of foreign stakes in Spain (Tascón and Carreras 2001; Tortella 2000 and 2008; Loscertales 2002; Castro 2010; Puig, Álvaro and Castro 2008a; Broder et al. 2014). When dealing with US investment in Spain, economic historians have also used the annual estimations of American stakes abroad published since the early $20^{\text {th }}$ century by the Treasury Department (Tascón 2003, 2008; Álvaro-Moya 2011, 
2012; Tascón and López Zapico 2014). Despite the limitations posed by such sources, these authors have added to the existing information about FDI distribution by home country and industry. They have also revealed a remarkable continuity in capital flows and business relationships between locals and foreigners during the middle decades of the $20^{\text {th }}$ century, under Franco's rule. Moreover, new research shows that the Spanish government was proactive in its search for foreign investors and technological assistance to undertake large industrial projects. Indeed, technological dependence prevented the Spanish government from taking full advantage of the nationalization opportunities that arose after the Second World War. The expropriation and public auction of German industrial assets is a case in point. Instead of transferring them to Spanish owners, most firms remained under the control of their former shareholders and managers. This procedure not only ensured the continuity of the business operations of German MNEs during the difficult postwar years, but would facilitate the full takeover of the Spanish subsidiaries in the new context of the 1960s and after (Puig and Álvaro 2007).

New approaches to the transfer of technology

The examination of technology transfer has traditionally relied on quantitative data on patents and licensing. Some of the studies conducted from the 1990s onwards have applied the same methodology. They offer a broad picture of the last two centuries consistent with traditional ideas of the Spanish economy as being structurally dependent on foreign technology (Molero 1979, 1993; Miranda 1998; Ortiz-Villajos 1999; Sáiz 1999, 2005; Cebrián 2001, 2005).

However, technology transfer goes beyond patents and licensing. Aware that it can also occur outside the industrial sector and/or through qualitative venues that call for alternative approaches and research methods, historians have begun to identify new areas, such as management education (Puig 2003b, 2003c, 2008; Puig and Fernández-Pérez 2003; Torres 
2016), management consulting (Kipping and Puig 2003; Kipping, Üsdiken and Puig 2004) and engineering consulting (Álvaro-Moya 2014; Castro and Sánchez 2014). As in other European countries, management education and business schools arose in the mid-20 century under a strong US influence. The technical assistance program included in the American aid of the 1950s (in the Marshall Plan in the case of other Western Europeans) was the basis of the first, state-promoted business schools, an initiative soon followed by private groups very close to Spanish business and political elites. Particularly in the last case, business schools were a response to the challenges posed by MNEs entering the market, in a context, however, of increasing professionalization and labor rationalization of domestic firms.

Management and engineering consulting also emerged under a strong foreign (this time US and French) influence. While management and engineering consulting and US firms entered the Spanish market through consulting services, joint ventures and strategic alliances with domestic firms (Kipping and Puig 2002, 2003; Álvaro-Moya 2014), the French engineering firms achieved a prominent position in the Spanish economy in the 1960s and early 1970s through technical assistance contracts (Castro and Sánchez 2014).

Finally, a broader and less quantitative approach to the transfer of technology is leading historians to explore the relationship between foreign MNEs and brands and trademarks (Sáiz and Pretel 2014; Pretel and Sáiz 2012). These studies suggest that patenting was closely related to direct investment and geographic proximity before 1880. By contrast, in the following decades, and at least until 1939 (the period these works focus on), multinationals used patenting as a way to protect future businesses as their international expansion accelerated, interests which would be exploited later on or (more frequently) not. 


\section{Case studies on MNEs transferring knowledge}

In the last few years, many collective and individual case studies on foreign MNEs have explored the formation of local entrepreneurial and managerial capabilities as well as the determinants of this process (Gómez Mendoza 1994; López Morell 2013; Álvaro-Moya 2007, 2014; Llonch 2014; Fernández-Pérez 2014; Puig 2003a; Puig and Álvaro-Moya 2015a, 2015b). According to these studies, although expatriates were crucial in the early stages of new subsidiaries, they tended to soon be replaced by Spanish-educated managers, even in technology-intensive areas. Economic nationalism certainly encouraged such practices, but the adoption of adaptation strategies by foreign MNEs and the availability of either experienced or promising Spain-based professionals played a significant role as well. Recent research highlights, in fact, the high technical level of Spanish managers and engineers, but also their lack of marketing, distribution and advertising skills. Technical and organizational knowledge spread within the subsidiaries through more or less institutionalized in-house training and personnel exchange programs.

Finally, historians have identified an issue worth further exploration; i.e. the circulation of codified and uncodified knowledge beyond subsidiaries and joint-ventures through the professionals moving on to other companies and/or teaching at educational and scientific institutions, eventually helping to establish new institutions and build lasting ties between these institutions and the multinational firms these professionals had once worked for Puig and Álvaro-Moya (2015b). This link between foreign MNEs and the local educational infrastructure constitutes, therefore, a new approach to technology transfer in line with what has been discussed in the previous section and of great interest to assess the long-term influence of multinationals in host economies. 


\section{Patterns of investment}

International business scholars have paid considerable attention to FDI national patterns and home-country effects on the strategies and behaviors of MNEs. Persuaded that such patterns and effects can be best understood in historical and comparative perspective, Spanish economic and business historians have set out to examine the dynamics of French, German, and American direct investment (Castro 2010; Loscertales 2002; López-Morell 2013; Puig, Álvaro and Castro 2008a; Puig and Castro 2009; Sánchez 2006).

By combining foreign trade and FDI flow statistics with highly detailed information from public and private archival sources, these studies have added considerably to our knowledge of the history of foreign MNEs in Spain. We know, for example, how and with what partners the Rothschild bank operated in our country (López-Morell 2013). We also have in-depth knowledge of the main actors and strategies of German investment in Spain from 1870 to 1920 (Loscertales 2002). And we have exhaustive analyses of the role played by the French administration and banking sector in French direct investment activities in $19^{\text {th }}$ and $20^{\text {th }}-$ century Spain (Sánchez 2006; Castro 2010). Last but not least, a long-term comparative analysis of French and German investment in Spain reveals that the core capabilities of foreign firms and their relationships with local partners spurred the rise and development of two distinct models of international investment, characterized as "political" and "technical", respectively (Puig and Castro 2009). Seeking for new markets, American capital, by contrast, used both technical and political local partners to accommodate to domestic politics and opportunities. In any case, these investment patterns worked also as a response to successive waves of capital inflows headed by different actors, but traditionally monopolized by French, British, German and American companies (Puig, Álvaro and Castro 2008a). 


\section{The local actors of inward FDI}

Firm demography studies and case studies have allowed the identification and analyses of the local actors of inward FDI, from business groups and family firms to professional associations, educational institutions and chambers of commerce (Otazu 1987; Loscertales 2002; Sánchez 2006; Puig and Torres 2008, 2015; García-Ruiz and Puig 2009; Castro 2010; Álvaro-Moya 2011, 2015; Puig and Álvaro-Moya 2015b). The historical alliances between MNEs and local firms have also been illustrated by national and regional entrepreneurial biographies (Torres 2000; Vidal 2005; Cabana 2006; Parejo 2011) and business monographies, as well as by new comprehensive studies on Spanish large family businesses (Fernández-Pérez and Lluch 2015). As noted in section 2, early research on FDI in Spain had already highlighted the role played by business groups and family firms in the entry of foreign capital through the exchange of local contacts and know-how for financial and technological resources. The recent studies aforementioned, however, stress the multi-sided character of the relationships between local and foreign actors and the continuity of such relationships in the long term.

Moreover, FDI was facilitated by professional associations, educational institutions and chambers of commerce, which not only provided foreign firms with host market information, but helped create and strengthen effective and lasting social networks. Existing studies also suggest that these institutions might have played a key role in the dissemination of ideas beyond subsidiaries, as well as in the development of a social and business environment favorable to MNE operations in Spain (Sánchez 2006; Puig and Álvaro 2004; Puig, Álvaro and Castro 2008a; Álvaro-Moya 2011; Castro 2010). "Soft" diplomacy might have enhanced these dynamics. 


\section{International aid programs and soft diplomacy}

The fiftieth anniversary of the Marshall Plan prompted a wave of research on the effects of the economic aid and technical assistance provided that the US provided to its allies. The "Americanization" of Western and Japanese firms and institutions became a favorite research topic (Djelic 1998; Kipping and Bjarvar 1998, Gourvish and Tiratsoo 1998; Engwall and Zamagni 1998, Zeitlin and Herrigel 2000, Barjot 2002, Barjot and Réveillard 2002, Barjot and Schröter 2002, Barjot, Lescent-Giles and Fèrriere 2002, Kipping and Tiratsoo 2002, Schröter 2005). Although Spain was not invited to join the Marshall Plan, in 1953 the Spanish and US governments reached a bilateral agreement that granted Spanish firms and other public and private institutions access to American know-how. In the early 21 st century, Spanish economic and international relations historians joined efforts to assess the extent and long term effects of such agreements (Niño 2003, 2015; Delgado and Elizalde 2005; Delgado and León 2011). Some of these studies identified a number of professional associations created in the context of American aid with close ties with foreign firms (Puig and Álvaro 2004; Álvaro-Moya 2012). The construction of the American military bases, as well as the "productivity missions" of Spanish businesspeople and managers sent to the United States would pave the way for modern engineering consulting firms and contributed to the later expansion of domestic construction companies (Puig and Torres 2008; Torres 2011; ÁlvaroMoya 2014).

International relations and cultural historical research has paid increasing attention to "soft" diplomacy; that is, the set of initiatives that seek to gain public support abroad by creating a positive social environment (Delgado 2009a, 2009b; Jiménez et al. 2015; Sánchez 2006; León 2006, 2011; Rodríguez 2011; Rodríguez, Delgado and Cull 2015; López-Zapico 2012; Montero 2008). This includes cultural, educational and scientific exchange programs. None of 
these studies, which have focused on France and the United States, have among their aims an analysis of the impact of these programs on inward FDI. But these initiatives facilitated the operations of foreign firms in at least two ways: by training the personnel of future foreign affiliates and by compensating for the state's nationalism and protectionism with a social and business environment favorable to FDI. These programs, moreover, might have helped to manage cultural diversity within the firms. In the case of the US, research has also shown how some of these soft-diplomacy initiatives, particularly those related to the motion picture industry, were used by foreign firms to overcome the strict limits imposed on outward capital flows during the autarky (León 2006, 2011).

\section{From inward to outward FDI}

The rise of Spanish multinationals, a late yet quite remarkable phenomenon that has underpinned the rapid growth of the Spanish economy in the late $20^{\text {th }}$ and early $21^{\text {st }}$ centuries, poses interesting questions about the many ways that Spanish firms learn and benefit from foreign MNEs (Durán 1996, 2005; Sánchez and Durán 1981). Do multinationals help local firms to go international? Do local partners learn from foreign MNEs? To what extent did economic nationalism promote the transfer of knowledge from MNEs to their Spanish subsidiaries and joint ventures through local management? Historians are making a relevant contribution to our understanding of Spain's new multinationals by unveiling strong and enduring links between some of these firms and their historical multinational partners (Puig, Álvaro and Castro 2008a, 2008b; Fernández-Pérez 2014). Many of such alliances were lasting and influential, what not only explains the continuity of foreign investments in spite of increasing governmental restrictions, but also created a path of dependency which favored a fruitful interaction between foreigners and local actors, including local managers and Spanish professional and educational institutions (Puig and Álvaro-Moya 2015b). 
Management scholars, however, have approached this topic far more effectively, examining the rise of multinational firms based in emerging markets with the tools of international business and developing new perspectives (Guillén 2005; Guillén and Tschoegl 2008; Guillén and García-Canal 2010). This leads us to a crucial issue: the limited impact of historical research outside its own academic boundaries and the inability or resistance to re-engage in a fruitful dialogue with other disciplines. Spanish historians, like their international peers, excel at borrowing and discussing concepts and theoretical frameworks taken from other disciplines, but often fail to disseminate their findings among their colleges. Historical theorizing should be a priority for future research.

\section{Conclusions and directions for future research}

Over the past two decades, economic and business historians have used new sources and perspectives to shed new light on the role of foreign MNEs in Spain's economic and social development. This research has resulted in a wealth of new empirical evidence, as well as a more critical approach towards the relationship of inward FDI and the Spanish variety of capitalism. By pointing to the persistent influence of foreign MNEs throughout Spain's long industrialization process, the contradictory effects of economic nationalism, the proactive role of local actors and the processes of internalization of foreign knowledge by both MNE subsidiaries and local firms, scholars have shifted their focus away from the roots of economic backwardness towards the complex world of MNEs and their interaction with local business actors. Although failed projects and disinvestment processes, which underpin the history of MNEs in contemporary Spain, continue to be neglected or under-researched, we contend that there is enough evidence to update and review the groundbreaking work of Muñoz from a historical and comparative perspective (Muñoz et al. 1978). This would help 
foreign MNEs find the place that they lack today in the many textbooks used by thousands of students of Spanish economic history.

The relatively late development of Spain makes it an ideal case study for testing international business theories, not only classical theories inspired by the historical experience of advanced, mainly Anglo-American, firms, but alternative theoretical frameworks based on emerging markets. However, one of the problems of the recent historical research is a lack of interaction with economists and management scholars. This explains the relatively low levels of academic relevance and visibility of most of the research reviewed in this article. To promote an interdisciplinary dialogue akin to that of the 1960s and 1970s and to increase their visibility in the highly competitive environment of the $21^{\text {st }}$ century, historians need stronger theoretical foundations and historical theorizing (Bucheli and Wadhwani 2014; Jones 2015). In our view, internalization theory (Verbeke and Kano 2015) has a high potential for historians concerned with at least five issues: 1) the entry and operation modes of foreign MNEs; 2) the bundling of MNE firm-specific advantages and local assets (including host country advantages), examined through joint ventures and other historical strategic alliances between foreign and Spanish actors; 3) the transfer of knowledge and organizational capabilities from MNEs to local firms; 4) the development of local managerial and entrepreneurial talent; and 5) the implications of previous international experience for the internationalization of Spanish enterprises.

The interplay between the foreign and local actors of international direct investment is at the core of the major reinterpretation of the long-term effects of MNEs in contemporary Spain that we are proposing here. We need to re-examine the historical evidence regarding the development of organizational capabilities under foreign influence, as well as link this process to the recent internationalization of Spanish firms. Such an approach should allow us 
to test internationalization theory against relevant historical experience, shedding light on the microeconomic dynamics of inward and outward FDI flows and thereby adding to the investment development path theory (Dunning and Narula 1996).

Finally, we propose that students of MNEs in Spain take a critical look at the impact of the period of economic transition between 1960 and 1986 on foreign and Spanish enterprises. Existing evidence does not deny the disrupting effects of Spain's entry into the European Union (the focus of recent management scholarship), but it reveals that by 1986 many Spanish businesspeople and institutions had already learned to deal with change and to look for and seize investment opportunities both inside and outside the country: this is the very nature of entrepreneurship, and an excellent starting point for integrating historical research into the study of international business.

\section{References}

Álvaro-Moya, Adoración. 2007. "Redes empresariales, inversión directa extranjera y monopolio: el caso de Telefónica, 1924-1965." Revista de Historia Industrial 34:65-96.

Álvaro-Moya, Adoración. 2011. "Hízose el milagro. La inversión directa estadounidense y la empresa española (c. 1900-1975)" Investigaciones de Historia Económica 7 (3): 358-368.

Álvaro-Moya, Adoración. 2012. La inversión directa estadounidense en España. Un estudio desde la perspectiva empresarial (c. 1900-1975). Madrid: Banco de España.

Álvaro-Moya, Adoración. 2014. "The Globalization of Knowledge-Based Services: Engineering Consulting in Spain (1953-1975).” Business History Review 88 (4): 681-707.

Álvaro-Moya, Adoración. 2015. "Networking capability building in the multinational enterprise: ITT and the Spanish adventure (1924-1945).” Business History 57 (7): 1082-1111.

Barjot, Dominique. 2002. Catching up with America. Productivity Missions and the Diffusion of American Economic and Technological Influence after the Second World War. Paris: Presses de l’Université de Paris-Sorbonne.

Barjot, Dominique, and Christophe Réveillard. 2002. L'américanisation de l'Europe occidentale au XX siècle. París: Presses de Université de Paris-Sorbonne. 
Barjot, Dominique, and Harm Schröter. 2002. Americanisation in 20th century Europe: Economics, Culture, Politics. Lille: CRHENO-Université Charles-de-Gaulle-Lille 3.

Barjot, Dominique, Isabelle Lescent-Giles, and Marc de Ferriere. 2002. L'Américanisation en Europe au XXe siècle: Economie, Culture, Politique. Lille, CRHEN-O/Presses de l'Université de Lille III.

Braña, F. Javier, Mikel Buesa, and José Molero. 1976. "Los orígenes y el desarrollo del capitalismo en España. La formación de un capitalismo periférico.” Información Comercial Española 14:119135.

Broder, Albert. 1979. Le role des interets étrangers dans la croissance économique de l'Espagne: 1815-1913. Etat, entreprise et histoire. Paris: Université Paris X.

Broder, Albert, Miguel Á. Pérez de Perceval Verde, Alejandro Sánchez Rodríguez, and Carmen Marchán Sanz, eds. 2014. La inversión extranjera en la minería española. Madrid: Instituto Geológico y Minero de España.

Bucheli, Marcelo, and R. Daniel Wadhwani. 2014. Organizations in Time: History, Theory, Methods. Oxford: Oxford University Press.

Cabana, Francesc, ed. 2006. Cien empresarios catalanes. Madrid: Lid.

Cameron, Rondo. 1971. Francia y el desarrollo económico de Europa, 1800-1914. Conquistas de paz y semillas de guerra. Madrid: Tecnos.

Campillo, Manuel. 1963. Las inversiones extranjeras en España, 1850-1950. Madrid: Manfer.

Cardoso, Fernando, and Enzo Faleto. 1979. Dependency and development in Latin América. Orlando: University of California Press.

Castro, Rafael. 2010. Génesis y transformación de un modelo de inversión internacional: el capital francés en la España del siglo XX. Madrid: Universidad Complutense de Madrid.

Castro, Rafael, and Esther Sánchez. 2014. "How Does Knowledge Cross borders? The SOFRE GROUP in the Spain of the Planning, 1959-1976." Industrial and Corporate Change. doi: 10.1093/icc/dtu026.

Cebrián, Mar. 2001.“Las fuentes del crecimiento económico español, 1964-1973.” Revista de Historia Económica 19:277-299.

Cebrián, Mar. 2005. "La regulación industrial y la transferencia internacional de tecnología en España (1959-1973)." Investigaciones de Historia Económica 3:11-42.

Clavera, Joan, Joan M. Esteban, M. Antònia Monés, Antoni Montserrat, and J. Ros Hombravella. 1973. Capitalismo español: de la autarquía a la estabilización (1939-1959). Madrid: Cuadernos para el Diálogo. 
Costa Campí, M.T. 1983. Financiación exterior del capitalismo español en el siglo XIX. Barcelona: Publicaciones de la Universidad de Barcelona.

Delgado Gómez-Escalonilla, Lorenzo. 2009a. Westerly Wind. The Fulbright Program in Spain. Madrid: Comisión Fulbright-LID Editorial Empresarial-AECID.

Delgado Gómez-Escalonilla, Lorenzo. 2009b. "La maquinaria de la persuasión. Política informativa y cultural de Estados Unidos en España." Ayer. Dossier: La ofensiva cultural norteamericana durante la Guerra Fría 75:1-36.

Delgado, Lorenzo, and María Dolores Elizalde, eds. 2005. España y Estados Unidos en el siglo XX. Madrid: Consejo Superior de Investigaciones Científicas.

Delgado, Lorenzo, and Pablo León Aguinaga. 2011. “Americanización de Europa, Guerra Fría y estudios históricos: jalones de una trayectoria. Introducción.” Historia del Presente 17:5-11.

Djelic, Marie-Laure. 1998. Exporting the American Model. The Postwar Transformation of European Business. Oxford: Oxford University Press.

Dunning, John, and Sarianna Lundan. 2008. Multinational Enterprises and the Global Economy. London: Edward Elgar.

Dunning, John, and Rajneesh Narula, eds. 1996. Foreign direct investment and governments. London: Routledge.

Durán, Juan José, ed. 1996. Multinacionales españolas I. Algunos casos relevantes. Madrid: Pirámide.

Durán, Juan José, ed. 1998. Multinacionales españolas II. Algunos casos relevantes. Madrid: Pirámide.

Durán, Juan José, coord. 2005. La empresa multinacional española. Estrategias y ventajas competitivas. Madrid: Minerva.

Durán, Juan José. 2006. "El auge de la empresa multinacional española." Información Comercial Española 2881:13-34.

Engwall, Lars, and Vera Zamagni. 1998. Management education in historical perspective. Manchester: Manchester University Press.

Evans, Peter. 1979. Dependent Development. Princeton: Princeton University Press.

Fanjul, Enrique, and Julio Segura. 1977. Dependencia productiva y exterior de la economía española: 1960-1970. Madrid: Fundación INI.

Fernández-Pérez, Paloma. 2014. "A neglected factor in the history of multinationals of emerging economies: The management of cultural diversity. The case of Acerinox, 1964-2000." XI Congreso Internacional de la AEHE, Madrid, CUNEF, September.

Fernández-Pérez, Paloma, and Andrea Lluch. 2015. Familias empresarias y grande empresas familiares en América Latina y España: una visión de largo plazo. Madrid: Fundación BBVA. 
Gallego, Martín. 1975. "Las inversiones de las multinacionales USA y el desarrollo industrial español." Economía Industrial 133:31-45.

García Delgado, José Luis, and Julio Segura. 1977. Reformismo y crisis económica. La herencia de la dictadura. Madrid: Saltés.

García Ruiz, José Luis, and Núria Puig. 2009. "AmCham Spain and the transformation of Spanish business, 1917-2007." In American Firms in Europe (1880-1980). Strategy, Identity, Perception and Performance, edited by Hubert Bonin and Ferry de Goey, 385-409. Droz: Genève.

Gerschenkron, Alexander. 1962. Economic backwardness in historical perspective, a book of essays. Cambridge, Mass.: Belknap Press of Harvard University Press.

Gómez Mendoza, Antonio. 1994. El "Gibraltar económico": Franco y Riotinto, 1936-1954. Madrid: Civitas.

Gourvish, Terry, and Nick Tiratsoo. 1998. Missionaries and Managers: American influences on European management education, 1945-1969. Manchester: Manchester University Press.

Guillén, Mauro. 2000. "Business Groups in Emerging Economies: A Resource-Based View." Academy of Management Journal 43 (3): 362-380.

Guillén, Mauro. 2005. The Rise of Spanish Multinationals: European Business in the Global Economy. Cambridge and New York: Cambridge University Press.

Guillén, Mauro, and Esteban García-Canal. 2010. The New Multinationals. Spanish Firms in a Global Context. Cambridge and New York: Cambridge University Press.

Guillén, Mauro, and Adrian Tschoegl. 2008. Building a Global Bank: The Transformation of Banco Santander. Princeton: Princeton University Press.

Jiménez, Francisco, Javier Rodriguez, Lorenzo Delgado Gómez-Escalonilla, and Nicholas J. Cull. 2015. US Public Diplomacy and Democratization in Spain. Selling Democracy? New York: Palgrave MacMillan.

Jones, Geoffrey. 2005. Multinationals and global capitalism from the nineteenth to the twenty-first century. Oxford: Oxford University Press.

Jones, Geoffrey. 2014. "Firms and global capitalism." In The Cambridge History of Capitalism, edited by Larry Neal and Jeffrey G. Williamson, 169-200. Cambridge, Mass: Cambridge University Press.

Jones, Geoffrey. 2015. "Editor's Introduction". Special issue on global business. Business History Review 89 (3): 403-404.

Kipping, Matthias, and Ove Bjarvar. 1998. The Americanisation of European Business: The Marshall Plan and the Transfer of US Management Models. New York: Routledge. 
Kipping, Matthias, and Núria Puig. 2003. "Entre influencias internacionales y tradiciones nacionales: Las consultoras de empresa en la España del siglo XX." Cuadernos de Economía y Empresa 17:105:137.

Kipping, Matthias, and Nick Tiratsoo. 2002. Americanisation in 20th century Europe: Business, Culture, Politics, Vol. II. Lille, CRHENO-Université Charles-de-Gaulle-Lille 3.

Kipping, Matthias, Behlül Üsdiken, and Núria Puig. 2004. "Imitation, Tension and Hybridization: Multiple "Americanizations" of Management Education in Mediterranean Europe." Journal of Management Inquiry 13 (2): 98-108.

Kock, Carl J. and Mauro Guillén. 2001. "Strategy and Structure in Developing Countries: Business Groups as an Evolutionary Response to Opportunities for Unrelated Diversification.” Industrial and Corporate Change 10 (1): 77-113.

León Aguinaga, Pablo. 2006. "El comercio cinematográfico como instrumento de la acción norteamericana en España durante la segunda guerra mundial." Cuadernos de Historia Contemporánea 28:303-322.

León Aguinaga, Pablo. 2011. Sospechosos Habituales. El cine norteamericano, Estados Unidos y la España franquista, 1939-1960. Madrid: CSIC.

Lipsey, Robert E.2002. "Home and host country effects of FDI." Cambridge, MA: NBER Working Paper 9293.

Llonch, Montserrat. 2014. "Direct foreign investment, technological change and local talent building: the case of Lyon-Barcelona." Paper presented at the XI Congreso Internacional de la AEHE, CUNEF, Madrid, September.

López Zapico, Misael Arturo. 2012. "Acciones y percepciones: la diplomacia, la economía política y la prensa escrita en las relaciones hispanonorteamericanas durante el tardofranquismo y los inicios del proceso democratizador." PhD diss., Universidad de Huelva.

López-Morell, Miguel, A. 2013. The House of Rothschild in Spain. London: Asghate.

Loscertales, Javier. 2002. Deutsche Investitionen in Spanien, 1870-1920. Stuttgart: Franz Steiner Verlag.

Miranda, José Antonio. 1998. La industria del calzado en España. Alicante: Instituto de cultura Juan Gil-Alber.

Ministerio de Comercio. 1977. Censo de inversiones extranjeras. Madrid: Dirección General de Transacciones Exteriores.

Molero, José. 1979. “Las empresas de ingeniería.” Información Comercial Española 552:59-71.

Molero, José. 1993. "Innovación y cambio tecnológico." In Lecciones de economía española, edited by José Luis García Delgado and Rafael Myro. Madrid: Civitas. 
Montero Jiménez, José Antonio. 2008. “Imágenes, ideología y propaganda. La labor del Comité de Información Pública de los Estados Unidos en España.” Hispania 68 (208): 211-234.

Moran, Theodore H. 1974. Multinational Corporations and the Politics of Dependence: Copper in Chile. Princeton: Princeton University Press.

Muñoz, Juan. 1969. El poder de la banca en España. Madrid: Zero.

Muñoz, Juan, Santiago Roldán, and Ángel Serrano. 1978. La internacionalización del capital en España, 1959-1977. Madrid: Edicusa.

Nadal, Jordi. 1975. El fracaso de la revolución industrial en España, 1814-1913. Barcelona: Ariel.

Niño, Antonio. 2003. "50 años de relaciones entre España y Estados Unidos." Cuadernos de Historia Contemporánea 25:9-33.

Niño, Antonio. 2015. "El modelo de modernización 'estadounidense' y sus efectos en España y América Latina." Revista complutense de historia de América 41:15-19.

Ortiz-Villajos, José M. 1999. Tecnología y desarrollo económico en la historia contemporánea. Estudio de las patentes registradas en España entre 1882 y 1935. Madrid: Oficina Española de Patentes y Marcas.

Otazu, Alfonso de. 1987. Los Rothschild y sus socios españoles (1820-1850). Madrid: O Hs.

Parejo, Antonio. 2011. Grandes empresarios andaluces. Madrid: Lid.

Prebisch, Raúl. 1950. The economic development of Latin America and its principal problems. New York: United Nations.

Pretel, David, and Sáiz, Patricio. 2012. "Patent Agents in the European Periphery: Spain (18261902)." History of Technology 31:103-125.

Puig, Núria. 2003a. Constructores de la química española. Bayer, Cepsa, Puig, Repsol, Schering y La Seda. Madrid: LID.

Puig, Núria. 2003b. "The americanization of a European latecomer: Transferring US management models to Spain, 1950s-1970s." In Americanization in 20th century Europe: Business, Culture, Politics, edited by N. Tiratsoo, M. Kipping, 259:275, Lille.

Puig, Núria. 2003c. "Educating Spanish managers. The United States, modernizing networks, and business schools in Spain, 1950-1975." In Inside the Business Schools: The Content of European Business, edited by Rolv Petter Amdam, Ragnhild Kvalshaugen and Eirinn Larsen, 58:86. Oslo: Copenhagen Business School Press.

Puig, Núria. 2008. "Business Education in Spain.” Business History Review 82:329-358.

Puig, Núria, and Paloma Fernández-Pérez. 2003. "The Education of Spanish Entrepreneurs and Managers: Madrid and Barcelona Business Schools, 1950-1975.” Paedagogica Historica 39 (5): 651:672. 
Puig, Núria, and Adoración Álvaro. 2004. "La guerra fría y los empresarios españoles: la articulación de los intereses económicos de Estados Unidos en España, 1950-1975." Revista de Historia Económica XXII (2): 387-424.

Puig, Núria, and Adoración Álvaro. 2007. "Misión imposible: la expropiación de las empresas alemanas en España, 1945-1975.” Investigaciones de Historia Económica 7:103-132.

Puig, Núria, and Adoración Álvaro-Moya. 2015a. "FDI long-term effects on host economies' managerial talent. US investment in 20th century Spain (1920s-1970s)." Multinationals and the organization of work. Re-Work: International Research Center, Humboldt University, Berlin. April 9-10.

Puig, Núria, and Adoración Álvaro-Moya. 2015b. "La huella del capital extranjero en España: un análisis comparado." Revista de Historia Industrial 58:269-405.

Puig, Núria, and Rafael Castro. 2009. "Patterns of International Investment in Spain, 1850-2005." Business History Review 83:505-537.

Puig, Núria, and Eugenio Torres. 2008. Banco Urquijo. Un Banco con Historia (1918-2008). Madrid: Turner.

Puig, Núria, and Eugenio Torres. 2015. "Grupos empresariales en la España contemporánea: El Grupo Urquijo, 1851-1982.” América Latina en la Historia Económica 22 (2): 160-197.

Puig, Núria, Álvaro Adoración, and Castro Rafael. 2008a. "Introducción histórica. Las empresas multinacionales en España.” In Los número uno en España, edited by Francesc Ribera Raichs, 19-45. Barcelona: Dobleerre.

Puig, Núria, Adoración Álvaro-Moya, and Rafael Castro. 2008b. "European Challenges and Opportunities: The Role of Europe in the Internationalization of Spanish Firms." In The European Enterprise. Historical Investigation into a Future Species, edited by Harm Schröter. Berlín: Springer.

Rodríguez Jiménez, Francisco Javier. 2011. "¿"Misioneros de la Americanidad"?: promoción y difusión de los American Studies en España, 1969-75.” Historia del Presente 17:55-69.

Rodríguez Jiménez, Francisco Javier, Lorenzo Delgado, and Nicholas J. Cull. 2015. US Public Diplomacy and Democratization in Spain. Selling Democracy? London: Palgrave Macmillan.

Roldán, Santiago, and José Luis García Delgado. 1973. La formación de la sociedad capitalista en España, 1914-1920. Madrid: Confederación Española de Cajas de Ahorro.

Rostow, Wal Whitman. 1960. The Stages of Economic Growth: A Non-Communist Manifesto. Cambridge, Mass: Cambridge University Press.

Sáinz, Fernando. 1965. "Historia de las inversiones extranjeras en España (1814-1959)." Boletín de Estudios Económicos 65:375-408. 
Sáiz, Patricio. 1999. Invención, patentes e innovación en la España contemporánea. Madrid: Oficina Española de Patentes y Marcas.

Sáiz, Patricio. 2005. “Investigación y desarrollo.” In Estadísticas Históricas de España. Siglos XIX y $X X$, edited by Albert Carreras and Xavier Tafunell. Bilbao: Fundación BBVA.

Sáiz, Patricio, and David Pretel. 2014. "Why Did Multinationals Patent in Spain? Several Historical Inquiries." In Organizing Global Technology Flows: Institutions, Actors, Processes, edited by Pierre-Yves Donzé and Shigehiro Nishimura, 39-59. London: Routledge, International Studies in Business History.

Sánchez Albornoz, Nicolás. 1968. España hace un siglo: una economía dual. Barcelona: Ariel.

Sánchez, Esther. 2006. Rumbo al sur. Francia y la España del desarrollo (1958-1969). Madrid: CSIC.

Sánchez Muñoz, and Juan José Durán Herrera. 1981. "La inversión española en el exterior." Papeles de economía española 9:239-256.

Sardà Dexeus, Joan. 1948. Política monetaria y monetaria y las fluctuaciones de la Economía española en el siglo XIX. Madrid: Instituto de Economía Sancho de Moncada.

Schröter, Harm. 2005. The Americanization of the European Economy. A compact survey of American economic influence in Europe since the 1880s. Dordrecht: Springer.

Tamames, Ramón. 1967. Introducción a la economía española. Madrid: Alianza.

Tamames, Ramón. 1977. La oligarquía financiera en España, Barcelona: Planeta.

Tascón, Julio. 2003. "Capital internacional antes de la "internacionalización del capital” en España, 1936-1959.” In Los empresarios de Franco. Política y economía en España, 1936-1957, edited by Glicerio Sánchez and Julio Tascón, 281-306. Barcelona: Crítica.

Tascón, Julio, ed. 2008. La inversión extranjera en España. Madrid: Minerva.

Tascón, Julio, and Albert Carreras. 2001. "Investissements étrangers et intérêts suisses en Espagne (1936-1946). ” In La Suisse et l'Espagne. De la République à Franco (1936-1946), edited by Mauro Cerrutti, Sébastien Guex and Peter Huber, 463-481. Lausanne: Antipodes.

Tascón, Julio, and Misael A. López Zapico. 2014. "U.S. Direct Investment in Spain during the LateFrancoism and the Transition to Democracy. Reasons for its behavior." Historia Actual Online 34:7-24.

Torres, Beatriz. 2016. Los orígenes del IESE. Madrid: Lid.

Torres, Eugenio. 2000. Los cien empresarios españoles del siglo XX. Madrid: Lid.

Torres, Eugenio. 2011. Origen, crecimiento e internacionalización de las grandes empresas españolas de la construcción (1900-2008). Bogotá: Universidad de los Andes, Cátedra Corona.

Tortella, Gabriel. 1973. Los orígenes del capitalismo en España. Banca, industria y ferrocarriles, 1829-1874. Madrid: Tecnos. 


\section{Journal of Evolutionary Studies in Business}

Tortella, Teresa. 2000. Una guía de fuentes sobre inversiones extranjeras en España (1780-1914). Madrid: Banco de España.

Tortella, Teresa. 2008. "La inversión extranjera a través del Archivo del Banco de España (19161966).” In La inversión extranjera en España, edited by Julio Tascón, 49-84. Madrid: Minerva.

Valdaliso, Jesús María. 2006. La familia Aznar y sus negocios (1830-1983). Madrid: Marcial Pons.

Valdaliso, Jesús María, and Manuel Torres. 2012. Grupo Aznar: 150 aniversario 1861-2011. Madrid: Ediciones El Viso.

Velarde, Juan. 1969. Sobre la decadencia económica de España. Madrid: Tecnos.

Velarde, Juan. 1975. "Las inversiones privadas extranjeras en España en el periodo 1960-1970." Boletín de Estudios Económicos 30 (96): 911-930.

Verbeke, Alain, and Liena Kano. 2015. "The New Internalization Theory and Multinational Enterprises from Emerging Economies.” Business History Review 89 (3): 415-445.

Vernon, Raymond. 1971. Sovereignty at Bay: The Multinational Spread of US Enterprises. New York: Basic Books.

Vidal, Javier. 2005. Cien empresarios valencianos. Madrid: Lid.

Wilkins, Mira. 1998. "Multinational Enterprises and Economic Change.” Australian Economic History Review 38 (2): 103-34

Wilkins, Mira. 2009. "The History of the Multinational Enterprise." In The Oxford Handbook of International Business, edited by Alan M. Rugman, 3-38. Oxford: Oxford University Press.

Wilkins, Mira. 2010. "Multinational Enterprises and the Varieties of Capitalism". Business History Review 84 (4): 638-645.

Zeitlin, Jonathan, and Gary Herrigel. 2000. Americanization and its limits. Reworking US technology and management in post-war Europe and Japan. Oxford: Oxford University Press.

This is an Open Access article distributed under the terms of the Creative Commons Attribution-Non-Commercial-No Derivatives License (http://creativecommons.org/licenses/by-nc-nd/4.0/), which permits non-comercial re-use and distribution, provided the original work is properly cited, and is not altered or transformed in any way. 